\title{
Selection of Contractors for a Housing Development Project in India by using an Integrated Model
}

\author{
Rajaprasad, S.V.S. ${ }^{1}$ \\ ${ }^{1}$ National Institute of Construction Management and Research (NICMAR), Hyderabad, India \\ *Corresponding E-mail: rajaprasad@nicmar.ac.in
}

Received 22 January 2018; Revised 14 May 2018; Accepted 29 May 2018

DOI: https://10.30880/ijscet.2018.09.01.005

\begin{abstract}
The Indian construction industry forms an integral part of the economy and a conduit for a substantial part of its development investment, is poised for growth on account of urbanization, economic development and peoples rising expectations for improved quality of living. Housing construction is usually executed or coordinated by contractors who specialize in one type of construction such as residential or commercial building. The completion of housing projects within the projected time span has always been the most challenging task for the construction organizations and it is found that many construction projects have been unsuccessful in delivering the projects at time, cost and quality which the clients and their consultants had perceived before the starting of the project and thus, it is important for the management to efficiently design a plan of action to achieve the goals and requirements. To accomplish the requirements of construction planning, identifying and selection of an appropriate contractor for housing development is a crucial decision making process. The study presented a method for solving a contractor selection problem in an Indian housing development project using combination of analytic hierarchy process and zeros one integer linear programming for allocating housing construction works to contractors. The proposed integrated model will provide an encouraging result to select a contractor for a particular type of housing construction to fulfil the quality requirements and completion of project on time.
\end{abstract}

Keywords: Contractor, Criteria, Analytic hierarchy process, Zero one integer linear programming

\subsection{Introduction}

To meet the challenges of rapid urbanization, India needs well-performing cities and the integrated housing development will be the key. Private sector participation in housing is necessary to bridge the gap between demand and supply. The real estate sector is one of the most globally recognised sectors [1]. In India, real estate is the second largest employer after agriculture and is slated to grow at 30 per cent over the next decade [2]. The real estate sector comprises four sub sectors - housing, retail, hospitality, and commercial. The growth of this sector is well complemented by the growth of the corporate environment and the demand for office space as well as urban and semi-urban accommodations. Real Estate sector accounts for nearly 5 percent of the country's GDP [3]. The housing industry of India is one of the fastest growing sectors. A large population base, rising income level and rapid urbanization leads to growth in this sector.

To meet the requirements housing construction in India, contractors should be competent in applying planned and scheduled tasks into physical actions, as well as effectively communicate with their in-site team in order to be able to follow-up the implementation of tasks on site according to the original plan. Moreover, the contractors should be able to adequately manage interferences among materials' delivery schedules and master the work schedule as not to allow for any detraction from the original plans. In this regard, contractors should utilise monitoring and optimisation tools to precisely identify any deviations in scheduling in order to rapidly address such deviations to other stakeholders for necessary corrective action with no cost implications. Today there are increasing disputes and

Published by: Universiti Tun Hussein Onn Malaysia(UTHM) and Concrete Society of Malaysia (CSM) 58 http://penerbit.uthm.edu.my/ojs/index.php/IJSCET 
differences arising out of contractual relations between contractors and owners whether owners are individual, firms or public. Construction contracts have very sensitive arrangement of weaving many different agencies to perform various obligations to execute the job. Contractors' effectiveness in following up and controlling on-site teams and in resolving their related conflicts affecting schedule performance, as well as their competence in incorporating and managing the work schedules of subcontractors and suppliers (within the main project schedule), are also seen as important considerations. The competence of contractors in providing a high level of reliable and detailed inputs and deliverables in the early planning stages is crucial for the implementation of project planning in construction projects [4]. Understanding of performance aspects and management roles of project contractors is crucial for the best likelihoods of having more achievable outcomes from the execution of construction projects [5].

Now a day's housing projects are getting more complex. Because of that, the contractors that build these projects have to meet specific demands. Nowadays, the most important criterion for tendering in the Indian construction industry is price. This means that the contractor that offers the lowest price gets the work. Lowest price tendering might not be the best way to select a contractor. Accepting the lowest price is the basic cause of the project completion problems because very often lowering the price means lowering the quality and it is especially important to properly evaluate the contactor's capabilities. [6]. The opportunistic behaviour of contractors in low-bids models has been detected from many researchers in various countries and many studies of low bids have found that for the best economic results and good quality, the lowest bid is not considered sufficient to ensure the desired results [7].

It would be better to select a contractor and build in a team where the participants can trust each other, and work for the same goal leading to better working situations and more value for every partner in the team. One of the most important steps in every construction process is the selection of a contractor. The style of selection will vary according to needs, environment and contractual situations. Most of the clients are still following adhoc procedures which does not give contractors confidence that the system is sufficiently well considered. As a result, the current practice of selection does not guarantee the selection of able contractors. In the construction industry, experienced contactor is a strong requirement for the project's life. Thus, choosing the right contractor is one of the most key decisions in any project. Selection of the best contractor is a vital process in construction projects. Many factors that must be taken into consideration when selecting contractors. Improper selection of contractors might lead to poor quality of work, and delay in project duration. A contractor selection problem is a multi-criteria decision making process. The main objective of the study to select the appropriate contractors for different housing projects by using the analytic hierarchy process and zero one integer linear programming by considering a case study in India.

\subsection{Literature Review}

Project planning needs to be considered as a key in determining the overall success of a project rather than as a preliminary function used for developing project schedules and resource plans. The results of planning should be fully integrated and communicated to project contractors. [8]. The purpose of construction project management is to plan, coordinate and control the application of project objectives in the most effective way according to stakeholders' needs[9] It involves many processes and sub-processes and includes the definition of project scope, cost estimating, roles and responsibilities of the project team, project stakeholder management, as well as the utilization of planning and control methods and tools. These require knowledge of the fundamentals of project management in order to develop successful project plans and schedules [10] which are necessary for the delivery of the project to time, cost and quality objectives $[11,12]$. Where there is a lack of knowledge, the application of project management concepts will result in incomplete project plans and, hence, loss of project performance [13]. 
The roles of particular project stakeholders (i.e. owners, contractors, and site-based planners) in the development and control of construction planning should be clearly defined and coordinated for a successful project [4]. A number of these research studies have highlighted some initiatives regarding the assessment of potential effects of various factors, pertaining to the main participants including contractors in a project, on the success of project performance [14 -18].A questionnaire comprising of 46 factors was analyzed statistically to select subcontractors in Egyptian construction projects revealed that the flexibility and cooperation when resolving delays and reputation are the vital [19]. In the construction field, choosing an appropriate contractor is of key importance to quality. A mechanism was proposed which accounts for the assessment of the subcontractor not only during the construction stage of a project but also after construction in Poland.[20] In construction projects, especially in building projects, approximately $90 \%$ of the construction work is carried out by subcontractors. There are several reasons behind this high level of subcontracting, such as need for expertise in certain work packages, need for skilled labor to carry out several construction activities, utilization of specialized subcontractors for shortening time, increasing quality and decreasing cost, and sharing risks with subcontractors to protect themselves from uncertainties and unstable conditions of the market[21-25]. Selecting the right subcontractor for the right job is critical for not only for the successful completion of the project in question but also for the reputation and business continuity of the general contractor[26] In the literature, there are number of studies that focus on contractor selection practices in the construction industry. These studies can mainly be categorized into two groups, the studies that aim to identify the contractor selection criteria and their importance levels and the tools, techniques and/or methodologies for selection [25]. A study was conducted in Turkey to develop a multi objective optimization model to assist contractors in selecting the most appropriate subcontractors for all work packages based on timecost-quality performances using the genetic algorithm [27]. Selecting contractors in the Netherlands is often done by the criterion of lowest price. This leads to a lack of innovation and a loss of quality in the construction industry and suggested twelve criteria for the selection of contractors in the Dutch construction industry [28]. Project construction must be managed in an effective manner. The selection of a proper construction contractor increases chances of successful completion of a construction project. It can also fulfil the client goals, and keep the schedule of the cost, time and quality. So it is extremely critical to select an appropriate contractor in the process of construction management[5].Finding a new route has become important to create the best model for contractor selection [29].

In the past several multi criteria decision making techniques such as technique for order preference by similarity to ideal solution, analytic hierarchy process, simple additive weighting and artificial neural networks were adopted for contractor selection in construction industry but in the present study an integrated model using AHP and zero one integer linear programming was proposed.

\subsection{Housing Project - A case study}

A housing developer in a major city in India was planning to construct five different types of houses, single bedroom (P), two (Q), three bed room (R) independent houses, duplex houses (S) and villas (T) with an aim to fulfil the requirements of all income groups. The number of houses under each category is $42,66,54,8$ and 8 respectively. The plan of the project is represented in Figure 1.The developer has established a project team to monitor the aspects of construction and decided to allocate the execution activity to contractors. The developer has identified three contractors based on four criteria required for the projects with an aim allocate the different housing construction among them. The basis for identifying three contractors is to minimize administrative expenses and to improve the monitoring of construction activity. This two stage supply chain with three contractors and five different types' construction with an objective to allocate a set of contractor to a particular housing construction. 


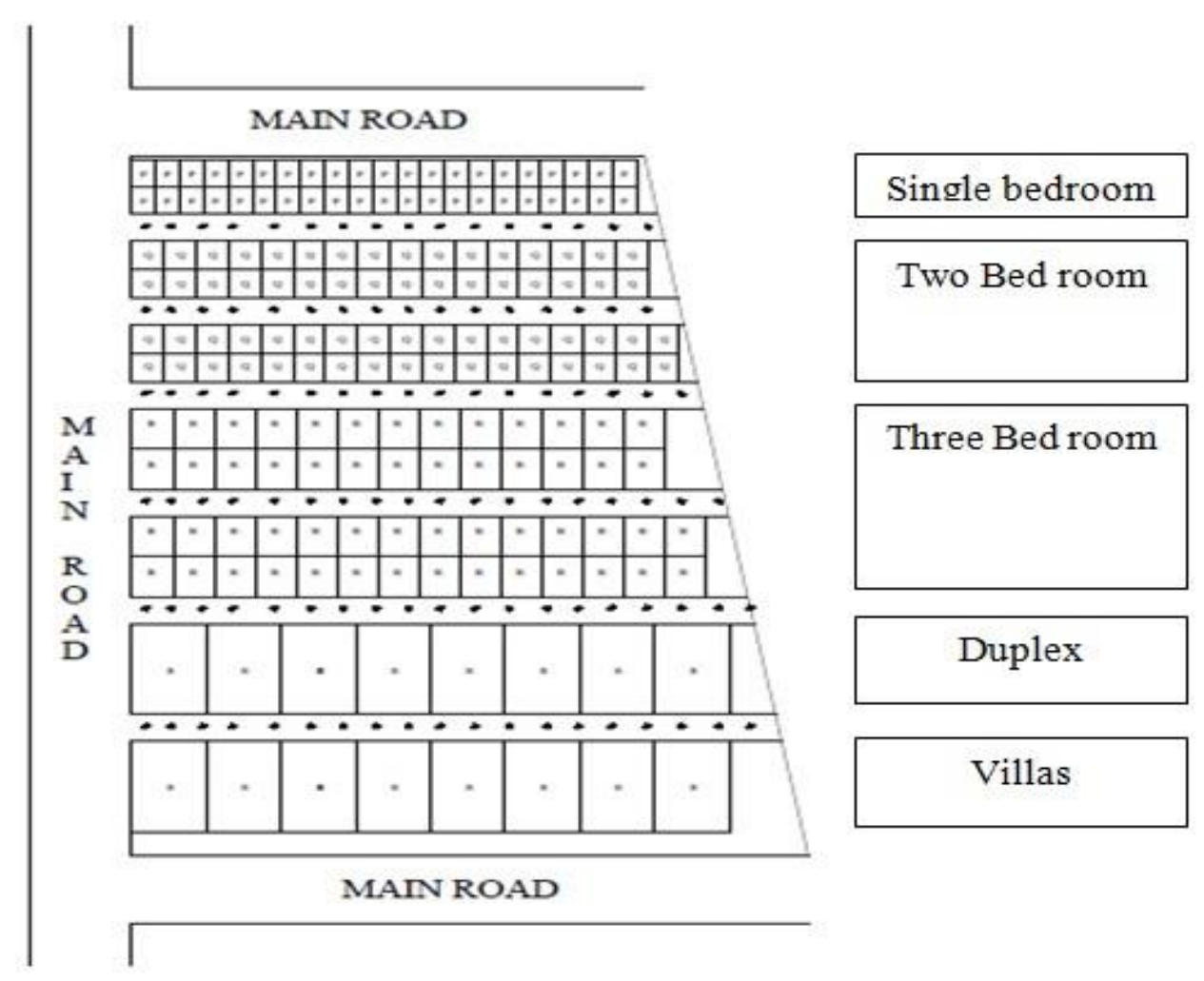

Figure 1: Plan of the housing project

\subsection{Methodology}

The analysis proposed AHP to calculate criteria weights and the ILP to formulate the problem.

\subsection{AHP Technique}

AHP was proposed to compute the criteria weights. The AHP, introduced by Thomas Saaty (1980), is an effective tool to solve complex problems involving multiple criteria and it is designed to handle situations that consider the subjective judgments of individuals. Brainstorming, sharing ideas and insights of the problem often leads to a more complete representation and understanding of the issues $[30,31]$.

\subsubsection{Step by step Procedure of AHP}

Step I:

$>$ To develop a hierarchy of the problem in terms of the overall goal, the criteria, and the decision alternatives.

Step II: Procedure for Synthesizing Judgments

$>$ Step II (A): Pair wise comparison of criteria and alternatives by Saaty scale (1 - Equally preferred 3 - moderately preferred, 5 - strongly preferred, 7- very strongly preferred and 9 - extremely preferred. Intermediate values between two adjacent judgements are allowed in case of compromising situation. Sum the values in each column of the pairwise comparison matrix [32].

$>$ Step II (B): Construct normalized pairwise comparison matrix by dividing each element in the pairwise matrix by its column total. 
$>$ Step II(C): Compute the average of the elements in each row of the normalized matrix to provide an estimate of the relative priorities of the elements being compared.

Step III: Consistency checking

An important consideration in terms of the quality of the decision relates to the consistency of judgments that the decision maker demonstrated during the series of pair wise comparisons. AHP provides a method for measuring the degree of consistency among the pair wise judgments provided by the decision maker by computing a consistency ratio. The ratio is designed in such a way that values of the ratio exceeding 0.10 are indicative of inconsistent judgments. If the degree of consistency is acceptable, the decision process can continue. If the degree of consistency is unacceptable, the decision maker should reconsider and possibly revise the pair wise comparison judgments before proceeding with the analysis. Step by step procedure of estimating consistency ration is detailed below;

$>$ Step III (A): Multiply the pair wise comparison matrix by the criteria weights to obtain a vector of values labelled "weighted sum."

$>$ Step III (B): Divide the elements of the vector of weighted sums obtained in Step 1 by the corresponding priority value.

$>$ Step III(C): Compute the average of the values computed in step 2. This average is denoted as $\lambda_{\max }$.

$>$ Step III(D): Compute the consistency index (CI): $\mathrm{CI}=\left(\lambda_{\max }-\mathrm{n}\right) /(\mathrm{n}-1)$, Where $\mathrm{n}$ is the number of items

$>$ Step III(E): Compute the consistency ratio (CR); CR = CI / RI

Where RI is the random index, which is the consistency index of a randomly generated pair wise comparison matrix. RI depends on the number of elements being compared and takes on the following values. RI values for $\mathrm{n}$ is equal to $1,2,3,4,5,6,7$ are $0.00,0.00,0.58,0.90,1.12$, 1.24 and 1.32 respectively.

\subsection{Zero One Integer Linear Programming}

Integer linear programming problems are three types. In pure ILP, all the variables are integers, in mixed type only some of the variables require to be integers; and in zero one ILP all the variables must have integer values, either zero or one [33]. ILP was applied to ascertain optimal suppliers and order quantity so as to maximize revenue [34], and to calculate optimal inventory lot sizing to reduce total inventory cost [35].

\subsubsection{Formulation of ILP}

The mathematical model developed to illustrate the objective function involving the allocation of housing construction to multiple contractors and vice versa so as to maximize the weightage. The number of contractors for a housing construction mainly depends on the decision of the developer and is treated as the first constraint. The maximum number of houses that can be allocated to a contractor is treated as second constraint. The total number of contractor assignments require for a house is third constraint. The formulated ILP model is presented hereunder,

Decision variable $\mathrm{E}_{\mathrm{xy}}=\{1$, contractor is allocated to house ' $\mathrm{y}$ '; 0 , otherwise $\}$, where,

$\mathrm{A}=$ contractor index, $\mathrm{x}=1,2 \ldots \mathrm{T}, \mathrm{T}=$ Total number of contractor

$\mathrm{B}=$ Houses index, $\mathrm{y}=1,2 \ldots \ldots \mathrm{V}, \mathrm{V}=$ Number of houses

$G_{x y}=$ Weightage of contractor 'A' for the house ' $y$ '

$\mathrm{C}=$ Minimum requirement of contractor for the house ' $\mathrm{y}$ '

$\mathrm{D}$ = Maximum number of houses allocated to contractor ' $\mathrm{A}$ '

$\mathrm{F}=$ Total number of contractor assignments needed for ' $\mathrm{V}$ ' number of houses

The objective function represents in Equation 1, the maximization of the preference weightage subject to,

Published by: Universiti Tun Hussein Onn Malaysia(UTHM) and Concrete Society of Malaysia (CSM) 62 http://penerbit.uthm.edu.my/ojs/index.php/IJSCET 
$\mathrm{T} \mathrm{V}$

Maximize $\mathrm{Z}=\sum \sum \mathrm{G}_{\mathrm{xy}} \mathrm{E}_{\mathrm{xy}}$

$\mathrm{x}=1 \mathrm{y}=1$

Minimum requirement of the number of contractor for each house is shown as Equation 2

$$
\sum_{\mathrm{A}=1}^{\mathrm{T}} \mathrm{E}_{\mathrm{xy}}=\mathrm{C}_{\mathrm{y}}
$$

The equation 3 represents allotment of maximum number houses to contractor.

$$
\underset{y=1}{V} E_{x y} \geq D_{x}
$$

The equation 4 represents the total contractor assignments shall not exceed the availability.

$$
\begin{aligned}
& \text { T V } \\
& x=1 \quad y=1 \\
& \sum \sum \mathrm{E}_{\mathrm{xy}} \leq \mathrm{F}
\end{aligned}
$$

The equation 5 ensures non-negative conditions.

$$
\mathrm{E}_{\mathrm{xy}}=1 \text { or } 0
$$

\subsection{Results}

The subjective judgements of the team of project engineers are the main source of data in the analysis. The previous experience of the project team with the contractors is vital in calculation of preference weightages. The decision of the developer is final regarding number of houses allocated to a contractor. The problem was formulated into integer programming model based on weightages calculated by AHP. The criteria considered are the company attributes, experience, financial capability and performance potential of the contractor. The developer and project team restricted only four criteria for selection of contractors basing on the scope of the project.

\subsection{Computation of Criteria Weights by AHP}

The AHP process starts with construction of hierarchy diagram in two levels to prioritize contractor for a housing type. The criteria for selection of houses and number of contractors were finalized by the developer and the structure was depicted in Fig 2. 


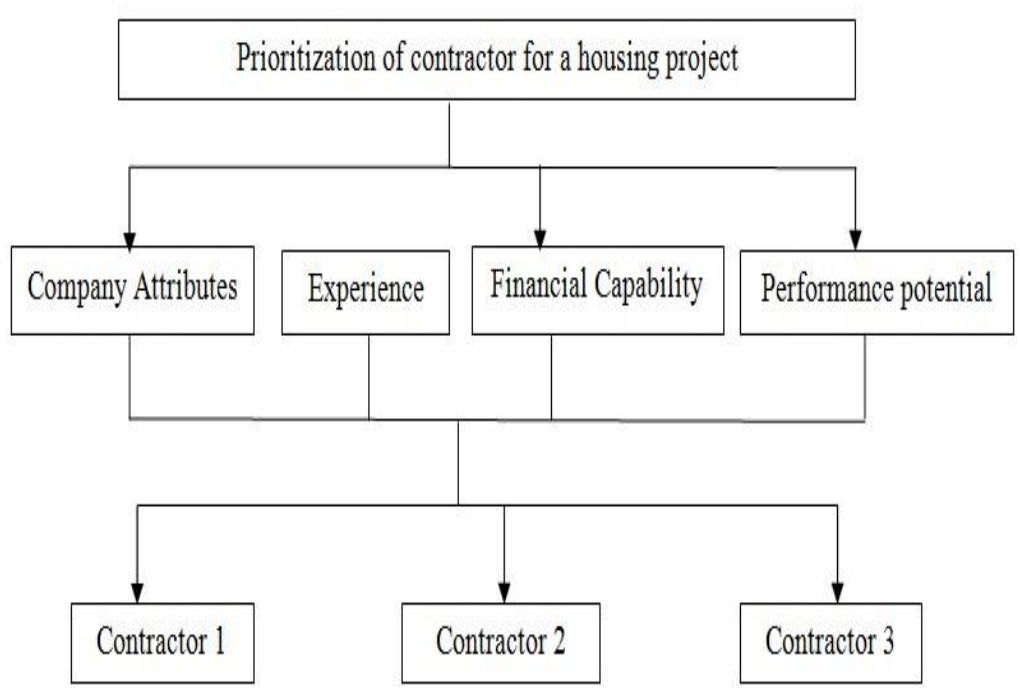

Figure 2: Two level hierarchy

\subsubsection{AHP Stage I}

AHP was applied in two stages. In the first stage the weights were calculated for six criteria basing on the subjective judgement of project team and weights are applicable for all the types of houses. The pair wise comparison matrix between criteria and calculated weights by AHP procedure was presented in Table 1.

Table 1: Pair wise comparison matrix and criteria weights

\begin{tabular}{|c|c|c|c|c|c|}
\hline & $\begin{array}{c}\text { Company } \\
\text { Attributes }\end{array}$ & Experience & $\begin{array}{c}\text { Financial } \\
\text { Capability }\end{array}$ & $\begin{array}{c}\text { Performance } \\
\text { potential }\end{array}$ & Criteria Weights \\
\hline $\begin{array}{c}\text { Company } \\
\text { Attributes }\end{array}$ & 1 & 2 & 6 & 7 & 0.56 \\
\hline Experience & $1 / 2$ & 1 & 1 & 5 & 0.21 \\
\hline $\begin{array}{c}\text { Financial } \\
\text { Capability }\end{array}$ & $1 / 6$ & 1 & 1 & 6 & 0.18 \\
\hline $\begin{array}{c}\text { Performance } \\
\text { potential }\end{array}$ & $1 / 7$ & $1 / 5$ & $1 / 6$ & 1 & 0.05 \\
\hline
\end{tabular}

The consistency ratio was found as 0.097 , which is less than 0.1 and the subjective judgements are consistent.

\subsubsection{AHP Stage II}

In stage II, the pair wise comparison of contractors using single criteria for one type of house is carried out. Single bed room independent house is considered to illustrate the process. Table 2 represent the pair wise comparison and weights of wholesalers relating to quality criteria based on subjective judgments.

Table 2: Weights of contractors to company attributes of Single bed room independent house 


\begin{tabular}{|c|c|c|c|c|}
\hline $\begin{array}{c}\text { Company } \\
\text { Attributes }\end{array}$ & Contractor 1 & Contractor 2 & Contractor 3 & Weights \\
\hline Contractor 1 & 1 & 4 & 9 & 0.73 \\
\hline Contractor 2 & $1 / 4$ & 1 & 3 & 0.20 \\
\hline Contractor 3 & $1 / 9$ & $1 / 3$ & 1 & 0.07 \\
\hline
\end{tabular}

Similarly the weights were calculated for experience, financial capability and performance potential. The consistency ratio was checked for pair wise comparison matrices relating to company attributes experience, financial capability and performance potential and found to be $0.01,0.00,0.00$ and 0.02 respectively and the comparisons are consistent as the ratio is less than 0.1 . The consolidated weight of criteria with respect to wholesalers is presented in Table 3.

Table 3: Weights of criteria vs contractors of Single bed room independent house

\begin{tabular}{|l|c|c|c|c|}
\hline & Company Attributes & Experience & Financial Capability & Performance potential \\
\hline Contractor 1 & 0.73 & 0.25 & 0.23 & 0.30 \\
\hline Contractor 2 & 0.20 & 0.07 & 0.08 & 0.10 \\
\hline Contractor 3 & 0.07 & 0.68 & 0.69 & 0.60 \\
\hline
\end{tabular}

The overall weights of contractors in relation to project 1is calculated by multiplying the criteria weights in stage I (Table 1) with the consolidated weights of criteria with respect to contractors (Table 3 ), as the hierarchy comprises of two levels and is presented in Table 4.

Table 4: Overall weights of contractors of Single bed room independent house

\begin{tabular}{|c|c|}
\hline Wholesaler(WS) & Overall weight \\
\hline Contractor 1 & 0.5177 \\
\hline Contractor 2 & 0.1461 \\
\hline Contractor 3 & 0.3362 \\
\hline
\end{tabular}

The procedure was continued for the remaining four types of houses and weights of contractors for projects are presented in the Table 5. The consistency ratio is checked at every stage of the analysis and the values are less than 0.1 .

Table 5: Preference weights

\begin{tabular}{|c|c|c|c|c|c|}
\hline Contractor & Single bedroom & Two bedroom & Three bedroom & Duplex & Villas \\
\hline 1 & 0.5177 & 0.4587 & 0.3523 & 0.3051 & 0.4918 \\
\hline 2 & 0.1461 & 0.3128 & 0.1677 & 0.5527 & 0.1934 \\
\hline 3 & 0.3362 & 0.2285 & 0.4800 & 0.1422 & 0.3148 \\
\hline
\end{tabular}

\subsection{Formulation of ILP}

The objective function is to maximize (as shown in Equation 6),

Published by: Universiti Tun Hussein Onn Malaysia(UTHM) and Concrete Society of Malaysia (CSM) 65 http://penerbit.uthm.edu.my/ojs/index.php/IJSCET 
$0.5177 \mathrm{E}_{11}+0.4587 \mathrm{E}_{12}+0.3523 \mathrm{E}_{13}+0.3051 \mathrm{E}_{14}+0.4918 \mathrm{E}_{15}+0.1461 \mathrm{E}_{21}+0.3128 \mathrm{E}_{22}+0.1677 \mathrm{E}_{23}+0.5527 \mathrm{E}_{24}$ $+0.1934 \mathrm{E}_{25}++0.3362 \mathrm{E}_{31}+0.2285 \mathrm{E}_{32}+0.4800 \mathrm{E}_{33}+0.1422 \mathrm{E}_{34}+0.3148 \mathrm{E}_{35}$

Subjected to,

Constraint 2 is to assign each criteria to only one contractor so that sum of all the contractors individual criteria equals to 1, so the constraint Equations 7 to 11 shows the condition.

$\mathrm{E}_{11}+\mathrm{E}_{21}+\mathrm{E}_{31}=1$

$\mathrm{E}_{12}+\mathrm{E}_{22}+\mathrm{E}_{32}=1$

$\mathrm{E}_{13}+\mathrm{E}_{23}+\mathrm{E}_{33}=1$

$\mathrm{E}_{14}+\mathrm{E}_{24}+\mathrm{E}_{34}=1$

$\mathrm{E}_{15}+\mathrm{E}_{25}+\mathrm{E}_{35}=1$

The constraint-2 is the number of houses allotted to contractor depends on the sum of weightages of that wholesaler and the Equations 12 to 14 shows the condition.

$\mathrm{E}_{11}+\mathrm{E}_{12}+\mathrm{E}_{13}+\mathrm{E}_{14}+\mathrm{E}_{15} \geq 2$

$\mathrm{E}_{21}+\mathrm{E}_{22}+\mathrm{E}_{23}+\mathrm{E}_{24}+\mathrm{E}_{25} \geq 2$

$\mathrm{E}_{31}+\mathrm{E}_{32}+\mathrm{E}_{33}+\mathrm{E}_{34}+\mathrm{E}_{35} \geq 1$

The constraint 3 is the total number of contractor assignments for set houses shall not exceed fifteen and this condition is shown in Equation 15.

$\mathrm{E}_{11}+\mathrm{E}_{12}+\mathrm{E}_{13}+\mathrm{E}_{14}+\mathrm{E}_{15}+\mathrm{E}_{21}+\mathrm{E}_{22}+\mathrm{E}_{23}+\mathrm{E}_{24}+\mathrm{E}_{25}+\mathrm{E}_{31}+\mathrm{E}_{32}+\mathrm{E}_{33}+\mathrm{E}_{34}+\mathrm{E}_{35} \leq 15$

The last constraint is all the decision variables are binary and is shown in Equation 16.

$\mathrm{E}_{11}, \mathrm{E}_{12}, \mathrm{E}_{13}, \mathrm{E}_{14}, \mathrm{E}_{15}, \mathrm{E}_{21}, \mathrm{E}_{22}, \mathrm{E}_{23}, \mathrm{E}_{24}, \mathrm{E}_{25}, \mathrm{E}_{31}, \mathrm{E}_{32}, \mathrm{E}_{33}, \mathrm{E}_{34}, \mathrm{E}_{35}=0$ or 1

The Equations 6 to 16 are solved by using LINDO v6.1 software and allocation a set of houses to a contractor is shown in Table 6. The contractor 1, 2 and 3 are allocated with two, two and one category of house respectively. The result of software is shown in Fig 3. From the output, $E_{11}, E_{15}, E_{22}, E_{24}$, and $\mathrm{E}_{33}$ allocated with binary number ' 1 '. $\mathrm{E}_{11}$ that is single bedroom independent houses is allocated to contractor 1.

Table 6: Allocation of contractors to different houses

\begin{tabular}{|l|c|c|c|}
\hline \multicolumn{1}{|c|}{ Type of houses } & Contractor 1 & Contractor 2 & Contractor 3 \\
\hline Single bedroom independent house & $\checkmark$ & & \\
\hline Two bed room independent house & & $\checkmark$ & \\
\hline Three bed room independent house & & & $\checkmark$ \\
\hline Duplex house & & $\checkmark$ & \\
\hline Villas & $\checkmark$ & & \\
\hline
\end{tabular}




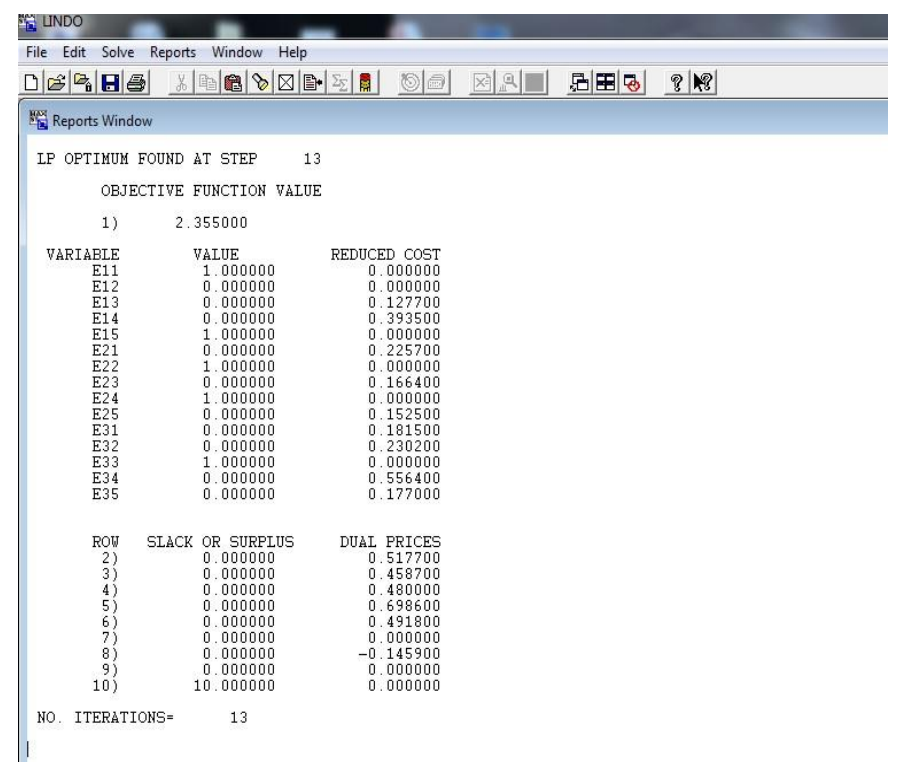

Figure 3: Results of the software

\subsection{Conclusions}

Contractor selection model using ILP was developed to select the contractor to construct a set of houses.The formulation of ILP model is based on preference weightages for a set of houses by contractors. The weightages are calculated based on the subjective judgements of project team by using AHP. The number of criteria can be increased or decreased depending on the scope of the work and clients requirements. In the present study, the team considered four criteria for selection of contractors. The model is tested for construction of houses and is found to be effective. Selection of contractors and construction of different houses in a housing development project is a crucial decision making process otherwise it may lead to affecting the quality as well as progress of the work.

The results of the study are useful to the housing development project to select a contractor based on criteria as it is difficult to fulfil all the criteria by a single contractor. Depending on the importance of criteria, a particular contractor can be selected. Allocation of a particular house is based on particular criteria makes construction process easy and it also creates competition among contractors to improve other areas so that a competitive environment is created. The criteria based contractor selection is crucial for housing projects requiring quality, reliability and completion of work during the execution.

\section{References}

[1] R. Shweta, and G. Prateek, "Current infrastructure scenario and rise in construction and allied industries in India”, International Journal of Science, Engineering and Technology Research, vol. 2, pp. 1573-78, 2013.

[2] T.Subramani, P.S. Sruthi, and M.Kavitha, "Causes of Cost Overrun In Construction", IOSR Journal of Engineering, vol. 04, pp. 1-7, 2014).

[3] G. Kalpana, and M. Venkataraman, "Affordable housing: Policy and practice in India", IIMB Management Review, vol. 27, pp. 129-140,2015.

[4] E. Johansen, and B. Wilson, "Investigating first planning in construction", Construction Management and Economics, vol. 24, pp. 1305-1314,2006.

[5] J.I. Alzahrani, and M.W.Emsley, "The impact of contractors' attributes on construction project success: A post construction evaluation” International Journal of Project Management, vol.31,pp. 313322, 2013.

[6] X. Huang, "An Analysis of the Selection of Project Contractor in the Construction Management Process", International Journal of Business and Management, vol. 6, pp. 25-37, 2011. 
[7] H. Doloi, A. Sawhney, K.C. Iyer, and S. Rentala, "Analysing factors affecting delays in Indian construction projects", International Journal of Project Management, vol. 30(4), pp. 479-489, 2012.

[8] A. Baldwin, and D. Bordoli, "Handbook for Construction Planning and Scheduling", First ed. John Wiley \& Sons, 2014.

[9] F. Harris, and R. McCaffer, "Modern construction management", Seventh ed. Wiley-Blackwell, 2013. [10] J. Heagney, "Fundamentals of project management", Fourth ed. American Management Association,2011.

[11] A.J.G. Babu, and N. Suresh, "Project management with time, cost, and quality considerations", European Journal of Operational Research, vol. 88, pp. 320-327, 1996.

[12] S.J. Whitty, and H. Maylor, “And then came Complex Project Management”, International Journal of Project Management, vol.27, pp. 304-310, 2009.

[13] Ahern, T., Leavy, B., Byrne, P.J., 2014. Complex project management as complex problem solving: A distributed knowledge management perspective. International Journal of Project Management, 32, 1371-1381.

[14] N.A.A. Bari, R. Yusuff, N. Ismail, A. Jaapar, and R. Ahmad, "Factors Influencing the Construction Cost of Industrialised Building System Projects”, Procedia - Social and Behavioral Sciences, vol. 35, pp. 689-696, 2012.

[15] N. Jaffar, A.H.A. Tharim, and M.N. Shuib, "Factors of Conflict in Construction Industry: A Literature Review”. Procedia Engineering, vol. 20, pp. 193-202, 2011.

[16] A. Enshassi, S. Mohamed, Z.A. Mustafa, and P.E. Mayer, "Factors affecting labour productivity in building projects in the Gaza strip" Journal of Civil Engineering and Management, vol.13, pp. 245 -

254, 2007.

[17] J. Tamosaitiene, Z. Turskisis and E.K. Zavadskas, "Modeling of Contractor selection taking into account different risk level", The 25th International Symposium on Automation and Robotics in Construction, 2008.

[18] Y. Li, X. Nie, and S. Chen, "Fuzzy Approach to prequalifying Construction Contractors" Journal of Construction Engineering and Management, vol.133, p. 40-49, 2007.

[19] M.M. Marzouk , E.A. Ahmed, and K. Mostafa, "Factors influencing sub-contractors selection in construction projects", HBRC Journal, vol. 9, pp. 150-158,2013.

[20] J.Piasny, and J. Pasławski, "Selection of subcontractors as the quality improvement tool in housing construction”, Procedia Engineering, vol. 122, pp. 274 - 281, 2015.

[21] J. Hinze, and A.Tracey, "The contractor-subcontractor relationship: the subcontractors' views" Journal of Construction Engineering and Management, vol.120, pp. 274-287, 1994.

[22] T.Y. Hsieh, "Impact of subcontracting on site productivity: Lessons learned in Taiwan" Journal of Construction Engineering and Management, vol.124, pp. 91-100, 1998.

[23] D. Arditi, and R. Chotibhongs, "Issues in subcontracting practice” Journal of Construction Engineering and Management, vol. 131, pp. 866-876,2005.

[24] J. Mbachu, "Conceptual framework for the assessment of subcontractors' eligibility and performance in the construction industry", Construction Management and Economics, vol. 26, pp. 471-484, 2008. [25] R.M. Choudhry, J.W. Hinze, M. Arshad, and H.F. Gabriel, "Subcontracting practices in the construction industry of Pakistan", Journal of Construction Engineering and Management, vol.138, 1353-1359,2012.

[26] A. Hartmann, and J. Caerteling, "Subcontractor procurement in construction: the interplay of price and trust” Supply Chain Management:An International Journal, vol. 15, pp. 354-362, 2010.

[27] P. Gul, L. Baris, and N.B. Befrin, "Subcontractor selection using genetic algorithm",Procedia Engineering, vol.123, pp. 432-440,2015.

[28] R. Favie, G. Abdalla, and G.J. Maas, "The best criteria for the selection of contractors in the Dutch construction industry", Proceedings of the CME25: Construction Management and Economics: Past, Present and Future, PP. 1-7, 2007.

[29] P. G. Ioannou and R. E. Awwad, "Below-average bidding method", Journal of Construction Engineering and Management, vol. 136, pp.936-946, 2010.

[30] T.L. Saaty, "TheAnalytic Hierarchy Process". New York: McGraw- Hill, 1980.

[31] M. Kamal, and A. Al-Harbi, “Application of the AHP in project management”, International Journal of Project Management, vol.19, pp.19 -27,2001.

[32] T. Evangelos, and H.M. Stuart, "Using the Analytic Hierarchy Process for Decision Making in Engineering Applications: Some Challenges", International Journal of Industrial Engineering: Applications and Practice, vol. 2, pp. 35-44,1995.

[33] H. A. Taha, "Operations Research: An Introduction”, 10th Edition Pearson,2017.

[34] G.H. Hong, S.C. Park, D.S. Jang, and H.M. Rho, “An Effective Supplier Selection Method for

Published by: Universiti Tun Hussein Onn Malaysia(UTHM) and Concrete Society of Malaysia (CSM) 68 http://penerbit.uthm.edu.my/ojs/index.php/IJSCET 
International Journal of Sustainable Construction Engineering \& Technology (ISSN: 2180-3242) Vol 9, No 1, 2018

Constructing a Competitive Supply -relationship", Expert Systems with Applications, vol.28, pp. 629639, 2005.

[35] W. Chirawat, K. Kritsana, and V. Paitoon, “Applying Genetic Algorithms for Inventory Lot-sizing Problem with Supplier Selection under Storage Capacity Constraints”, International Journal of Computer Science Issues, vol.9, pp.18-23, 2012. 